\title{
Assessment of Marketing Mix Strategies of the Hawassa Millennium Pepsi-Cola Plant
}

\author{
Busheto Belayneh $^{1} \quad$ Gudata Abara ${ }^{2}$ \\ 1.Hawasa University, College of Business and Economics, Department of Marketing Management, Hawasa, \\ Southern Ethiopia \\ 2.Wollega University, College of Business and Economics, Department of Accounting and Finance, Ethiopia
}

\begin{abstract}
The study deals with assessment of marketing mix of the MOHA soft drinks industry share company in Hawassa millennium Pepsi-Cola plant. Both primary and secondary data have been employed. Primary data obtained through interview and questionnaires, distributed to marketing managers and employees/staffs/ of the marketing department. The findings showed that the factory provides five types of products namely Pepsi Cola, Mirinda Orange, 7-Up, Mirinda Tonic, and Mirinda Apple. The plant has no any written pricing policy as a result the prices of the products are depends on different factors like; transportation charges, Competitors' costs, Economic factors, Gross profit costs, Overhead costs, Net profit, direct costs. The findings also shows that Hawassa millennium Pepsi-cola plant promotes its products by means of erecting artistic notice board in towns, at main public squares, sight-catching places, major outlets and inlets, public service stations and on vehicles and contributing to popular events by means of sponsoring various exhibitions etc. The recommendation made was to alleviate the problems in the distribution of the products (to fill the gap between the imbalances of demand and supply requirements), the factory must choose distributors that reach its customers most effectively and other intermediaries that add value to the distributive process. The factory has to do more to expand its local market coverage and increase its market share by selling the products even in rural areas.
\end{abstract}

Keywords: Marketing, Mix Strategy, Hawasa Millenium, Pepsi-Coca Plant

DOI: $10.7176 / \mathrm{JMCR} / 52-01$

\section{INTRODUCTION}

With the growing competition in the domestic and international markets, more demanding and assertive customers, rapid advancement in technology, and changing government policies and laws, the marketing environment has changed dramatically and is becoming more turbulent. Marketing is a major stakeholder in new product development, customer management, and value/supply-chain management, and marketing mix strategy provides concepts and processes for gaining a competitive advantage by delivering superior value to the business's customers( Kotler. 2007).

To survive and continue to grow in competitive and dynamic environment, every business organization tries to develop a set of controllable forces (marketing mix) which it uses as an adopting strategy (Inyanga, 1998). The marketing mix is hence a set of marketing tools that a firm uses to pursue its marketing objectives in its target market (Aigbiremolen, 2004). In a similar vein, marketing mix is viewed by Morden (1991) as a combination of detailed strategies, tactics, operational policies, programs, techniques and activities, to which resources may be allocated such that the firms marketing objectives are achieved. Hence, moving objectives and plans into reality of implementation and achievement is the primary function or role of the marketing mix. The organization in question, MOHA soft drinks industry Share Company is a domestic beverage industry. It was acquired from Ethiopian privatization agency and established on May 15,1996 with a paid up capital of Ethiopian birr 108,654000.The operational units include Nifas Silk plant, Tekle Haimanot plant, Summit plant, Gondor plant, Dessie plant, Bure plant and Hawassa plant. Hawassa and Bure plant started operation after acquisition. MOHA soft drinks industry Share Company is committed to producing safe, legal and quality beverage products and services that continue to satisfy the growing needs and requirements of customers and interested parties. Thus, the purpose of the study was to assess and evaluate the marketing mix strategy of the Hawassa Millennium Pepsi-cola Plant and to identify whether it was aligned with the target market to satisfy customer requirement.

\section{Statement of the Problem}

In fact when you run a business, everything might not be easily accomplished. Marketing mix strategies are the lifeblood of any company. Everyone knows that a marketing mix strategy influences the company's ability to generate profits or to stay in business. Not all too often good product ideas are funded because of a poor marketing mix strategy. Likewise Hawassa Millennium Pepsi-cola Plant might face with some problems while practicing (implementing) the marketing mix strategies. These are: transportation problem, shortage of trucks, economic problem, close competition in the market, remoteness of the area (the imbalances of demand to supply requirements), efficiency and effectiveness of the agents and Seasonality of consumption. In this regard, the 
research has undertaken the study to assess and evaluate the root causes of the marketing mix problems. Since marketing mix strategy study has not undertaken in the Hawassa millennium Pepsi-Cola plant for a long time, this study helps presently to fill the gap related to the company's marketing mix strategies such as the company products, the price charged, the promotional and place utility (distribution).

\section{Objectives of the Study}

The general objective of the study was to assess and evaluate the marketing mix strategies of the Hawassa Millennium Pepsi-cola Plant and to identify whether it is aligned with the target market to satisfy customer requirements.

The specific objectives are:

$>$ To identify and evaluate the company's product, pricing, promotional and distribution strategies to achieve its goals.

$>$ To identify problems the company encountering in the implementation of the marketing mix strategy and forward possible recommendations.

\section{Significance of the Study}

The ultimate goal of any business establishment is to remain in business profitably through production and sale of products or services. Without optimal profit, a business firm cannot survive. One of the core activities in a business company is having well-developed marketing mix strategies. The ultimate success or failure of a company depends on its marketing mix strategies. The initial investigation revealed that much has not been done on this core activity, or at least, it has been a neglected area. The study was therefore, intended to help the company management to redirect their attention to this highly essential function. It was focused on how marketing mix strategies used in order to enhance, maintain and attract customers and to identify how those tools should affect their marketing strategy and under taking such study is very crucial for any business entity so as to shape its marketing strategy. The study was worth doing because it was helped the company to look at its problems, to take in to the alternative consideration, and to give basic knowledge about marketing mix strategies and their significance in the MOHA Industry. It was also contributed towards the advancement of theoretical knowledge and served as a reference material for similar studies in future.

\section{MATERIALS AND METHODS}

In order to address the purpose of the study, both the primary and secondary data was collected. Schedule with close-ended questions and semi-structured personal interview used to collect primary data from marketing managers. Secondary data was obtained from published and unpublished documents; journals, annual reports, articles, different books and internet. The target population was managers and employees of the marketing department in Hawassa Millennium Pepsi-cola Plant totally 38 who are working in corporate sales and marketing department.

The selections of the respondents were carried out by using purposive (non- probability) sampling research method because no other departments were concerned about marketing strategies and the researchers took all the respondents of marketing staffs as a total population of the study.

In order to gather the data from relevant sources, both primary and secondary data collection instruments were used. The primary data was conducted in the form of personal interviews with marketing managers and closed and open-ended questionnaires were distributed to marketing department staffs. On the part of secondary data, written documents on marketing strategies, different reference books, journal articles, Internet web sites, policies, procedures, and document reports from MOHA was referred to make the study fruitful. The information that was obtained by using both instruments was integrated during data presentation and analysis section.

The collected data was analyzed and interpreted by using both qualitative and quantitative techniques. The data was collected by open-ended and interview questionnaires were analyzed through interpretation and conceptual generalization qualitatively. Closed-ended questionnaires were analyzed by using descriptive statics such as; figures, tables, percentages, Bar and Pie charts and Likert scale to make data meaningful.

\section{RESULTS AND DISCUSSION}

This chapter contains brief description of MOHA soft drinks industry share company particularly, Hawassa millennium plant and its marketing mix strategy namely: Product, price, promotion and place (distribution) strategy that constitutes for marketing mix strategy applications (practices).

This data analysis and interpretation part is composed of different data and information that were gathered through secondary data (written documents) and primary data (personal interviews with marketing managers and the questionnaires distributed to the marketing department staffs. 38 questionnaires were distributed to these staffs and out of which 35 were returned. 
Table 1: Sample respondent's opinion towards target customers

\begin{tabular}{|l|c|c|}
\hline \multirow{2}{*}{ Target customers } & \multicolumn{2}{|c|}{ Respondents in } \\
\cline { 2 - 3 } & Number & Percentage \\
\hline Individual customers & 19 & $54.3 \%$ \\
\hline Hotels, Restaurants and groceries & 13 & $37.1 \%$ \\
\hline Other intermediaries & 3 & $8.6 \%$ \\
\hline Total & 35 & $100 \%$ \\
\hline
\end{tabular}

Source: Own Survey, 2014

As the above table 3, shows, $19(54.3 \%)$ of the respondents said that the target markets are individual customers.13 (37.1\%) of the respondents replied hotels, restaurants and groceries whereas the rest of $3(8.6 \%)$ of the respondents said the target customers are other intermediaries like retailers and whole sellers.

Table 2: Sample respondent's response in relation to the company's product quality

\begin{tabular}{|l|c|c|}
\hline \multirow{2}{*}{ Item } & \multicolumn{2}{|c|}{ Respondents in } \\
\cline { 2 - 3 } & Number & Percentage \\
\hline The company's product quality & & $100 \%$ \\
\hline Very good & 35 & - \\
\hline Good & - & - \\
\hline Medium & - & - \\
\hline Poor & - & - \\
\hline Very poor & - & $100 \%$ \\
\hline Total & 35 & \\
\hline
\end{tabular}

Source: Own Survey, 2014

Table 2 shows, that all respondents $35(100 \%)$ have responded that the company's product qualities are quite surely very good and product qualities must exceed from the offering itself. It can be concluded that the company provides quality products. Furthermore, the managers also witnessed about the company's product quality. They said, firstly the company provides five(5) types of products (i.e. Pepsi-cola, Mirinda Orange, Mirinda Apple, Mirind Tonic and 7-up.) .These products are produced with excellent qualities because in almost all stages of production, the company gives a high emphasis for quality by objecting the lion share of the market. In each stage of the fermentations, there are laboratory technicians who controlled the quality of the company products.

The company product qualities in the production process and marketing perspectives are summarized as follows:

$>$ Quality control from production processes point of view: quality in MOHA soft drinks industry Share Company, Hawassa millennium plant has checked at every phase of production process. That is quality control was made at the very early stage of receiving raw materials through inspection centers. Most of the quality control were used to very technical statistical control methods identified using visual machines that shows problem or defect case of production process while the activity was on the progress.

$>$ Quality from market perspective with respect to color, clarity and foam of Pepsi cola: Here, the important point is that quality perspectives should be based on customers' preference, not on internal evaluation. So, the ultimate objectives of product quality should be to delight the customers in every way possible. Brand, price, promotion, distribution and quality are the main drivers that influence the purchasing decision of the Pepsi-cola drinker. In addition to the products quality, the customers' primary reason for buying and using the company products are:

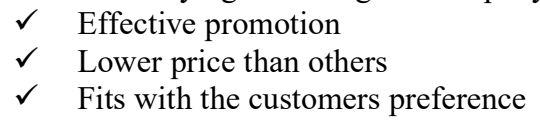

Table 3: Sample respondent's attitude towards the marketing mix activity of the company

\begin{tabular}{|l|c|c|}
\hline \multicolumn{1}{|c|}{ Item } & \multicolumn{2}{|c|}{ Respondents in } \\
\cline { 2 - 3 } & Number & Percentage \\
\hline How do you compare your company's promotional activity with its competitors? & & \\
\hline Much better & 6 & $17.1 \%$ \\
\hline Better & 7 & $20 \%$ \\
\hline About the same & 2 & $5.7 \%$ \\
\hline Not good & 16 & $45.7 \%$ \\
\hline Very poor & 4 & $11.4 \%$ \\
\hline Total & 35 & $100 \%$ \\
\hline
\end{tabular}

Source: own survey, 2014 
As one of marketing mix activity, promotion is the most influential among the other activities of marketing for company since it contacts its customers through it.

As the above table5 shows, $16(45.7 \%)$ of the respondents agreed that it is not good as competitors, $4(11.4 \%)$ of the respondents agreed that it is very poor, $13(37.1 \%)$ of the respondents agreed that it is better \& much better than that of competitors do in promotional activities and the only $2(5.7 \%)$ of the respondents agreed that it is about the same with its competitors. From this we can conclude that the factory has to design its promotional programs in a way that it attracts large number of potential customers and to become potential competitor with its competitors.

Table 4: Sample respondent's opinion concerning the prices of the company's products

\begin{tabular}{|l|c|c|}
\hline \multirow{2}{*}{ Prices of the company's product } & Respondents in & Percentage \\
\cline { 2 - 3 } & Number & - \\
\hline Very cheap & - & $34.3 \%$ \\
\hline Cheap & 12 & $65.7 \%$ \\
\hline Affordable & 23 & - \\
\hline Expensive & - & - \\
\hline Very expensive & - & $100 \%$ \\
\hline Total & 35 & \\
\hline
\end{tabular}

Source: Own Survey, 2014

As far as the theory is concerned, a large number of internal and external factors are examined before prices can be set. As one and mostly related with the sales since it is the only revenue generating marketing mix element, without selling a product no revenue can be generated, that's why price and sales are inversely related since price increases sales declines and vice-versa. As per the response, 23(65.7\%) of the respondents revealed that the pricing strategies of the company's products are affordable and $12(34.3 \%)$ said it is cheap. The response implies that the company pricing strategy is reasonable and affordable as a result most individual customers can handle this price.

However, the marketing managers were revealed that the company has not any written pricing policy. The prices of the products are depends on different factors like:

* Transportation charges:- Costs are incurred by transporting inputs and distributing the final products

* Competitors' costs: - Costs incurred in order to stand out competitors resulting in different pricing by competitors' pressure.

* Economic factor:- Inflation and deflation affects the pricing strategy

* Gross profit costs: - A margin that the company maintains in order to gain and survive after covering its direct costs.

* Overhead costs:- Costs that are incurred for different marketing activities, wages, salaries etc

* Net profit: - The ability of paying the owners in the form of dividends

* Direct costs:- Costs that are incurred by raw materials, taxies, machineries etc

Generally, the pricing strategy is not in a single way because there is a highly turbulent environment and the price also will change according to the conditions. The company like any other organization, prices its products to maximize its profits or the price must cover the whole costs and should gain some profits. It works hard to lower its production, overhead and administrative costs by cutting unnecessary operations, increase efficiency and productivity.

Table 5: The Company's products availability and accessibility

\begin{tabular}{|l|c|c|}
\hline \multirow{2}{*}{ Product availability and accessibility } & Respondents in \\
\cline { 2 - 3 } & Number & Percentage \\
\hline Excellent & 26 & $74.3 \%$ \\
\hline Very good & 5 & $14.3 \%$ \\
\hline Good & 4 & $11.4 \%$ \\
\hline Poor & - & - \\
\hline Very poor & - & - \\
\hline Total & 35 & $100 \%$ \\
\hline
\end{tabular}

Source: Own Survey, 2014

Distribution strategies are concerned with the channels of a firm that employ to make its goods available to customers. Placing the product of the company is producing in the place where it is convenient $\&$ comfortable for customers is the important decision part in case of deciding about placement.

Table 5 depicts, $26(74.3 \%)$ of the respondents said, the availability and accessibility of the products are admirable.5 (14.3\%) replied very- good and 4(11.4\%) of the respondents responded as it is good. The response implies the distribution system of the company is brilliant and determines the product's marketing presence and the buyers' accessibility to the product. In case of the Hawassa millennium Pepsi-cola plant, as respondents 
agreed distribution is the strongest part $\&$ it is the thing that makes the company the first choice of the customer than every competitor that produce soft drinks, as marketing department staffs respond that the company serves its customers at their destination with its transport. Thus, products availability is so nice and buyers can get the product easily in almost everywhere.

Table 6: Sample respondent's opinion towards the company's pricing methods

\begin{tabular}{|l|c|c|}
\hline \multirow{2}{*}{ Item } & \multicolumn{2}{|c|}{ Respondents in } \\
\cline { 2 - 3 } & Number & Percentage \\
\hline What method does the company used to set the prices? & 22 & $62.9 \%$ \\
\hline Competitor based method & 8 & $22.8 \%$ \\
\hline Cost plus pricing method & 5 & $14.3 \%$ \\
\hline Both & 0 & $0 \%$ \\
\hline Other mechanism & 35 & $100 \%$ \\
\hline Total & & \\
\hline
\end{tabular}

Source: Own Survey, 2014

As table 6 depicts, 22(62.9\%) of the respondents said, the company's pricing methods is competitor based. $8(22.8 \%)$ of respondents replied, the cost plus pricing method and $5(14.3 \%)$ of the respondents responded as both. The response implies that the company pricing method is competitor based in order to stand out competitors resulting in different pricing by competitors' pressure. Generally, the company's pricing method is not a simple task because there is a close competition environment and the pricing method also will change according to the competitors.

Table 7: The selling process of the company's products

\begin{tabular}{|l|c|c|}
\hline \multirow{2}{*}{ Process of selling the company products } & \multicolumn{2}{|c|}{ Respondents in } \\
\cline { 2 - 3 } & Number & Percentage \\
\hline Direct personal selling & 8 & $22.9 \%$ \\
\hline Direct online selling & - & - \\
\hline Indirect through the channels & 27 & $77.1 \%$ \\
\hline Word of mouth & - & - \\
\hline Telemarketing & - & - \\
\hline Total & 35 & $100 \%$ \\
\hline
\end{tabular}

Source: Own Survey, 2014

Table 7 shows, about $27(77.1 \%$ ) of the respondents agreed with the selling mechanism of the company's products are done by through indirect channels. The remaining $8(22.9 \%)$ answered that the selling process is through direct personal selling. The implication of selling for the company product is mainly through indirect channels. These indirect channels are intermediaries/agents who address the products from the producer to the consumers. The Hawassa millennium Pepsi-cola plant has its criteria to select the best intermediaries such as; they must have financial capacity, skilled and experienced manpower, necessary logistics (or transportation), they must be legal or licensed, has storage capacity, well structured, and reputed. They should also be capable of maintaining closer contact with the company and different roots under its chain.

Table 8: Sample respondent's opinion regarding marketing mix strategies

\begin{tabular}{|l|c|c|c|c|c|c|}
\hline \multicolumn{1}{|c|}{$\begin{array}{l}\text { Items am confident } \\
\begin{array}{c}\text { 1. } \\
\text { that I can perform my job } \\
\text { effectively. }\end{array}\end{array}$} & $\begin{array}{l}\text { Strongly } \\
\text { agree }\end{array}$ & Agree & Undecided & Disagree & $\begin{array}{l}\text { Strongly } \\
\text { disagree }\end{array}$ & Total \\
\hline Total & 21 & 8 & 4 & 2 & - & 35 \\
\hline Weights & 5 & 4 & 3 & 2 & 1 & 15 \\
\hline Percentage (\%) & $60 \%$ & $22.9 \%$ & $11.4 \%$ & $5.7 \%$ & - & $100 \%$ \\
\hline Weighted Frequency & 105 & 32 & 12 & 4 & - & 153 \\
\hline Calculated weighted mean & & & & & & 4.4 \\
\hline Table mean & & & & & 2.33 \\
\hline
\end{tabular}

Source: Own Survey, 2014

It is clear that the table 8 shows, the weighted frequency which accounts 4.4 is greater than the table mean which is 2.33. The majority of the respondents 29(82.9\%) who said Strongly Agree and Agree perform their duties effectively. $2(5.7 \%)$ of the respondents responded that they disagree with the statement. The rest of $4(11.4 \%)$ preferred to stay in undecided.

This implies that the employees can perform the marketing mix strategies of the company effectively. Hence, the Marketing mix strategies are the means by which the marketing objectives will be achieved, the employees and managers of the marketing department are genuinely performing their duties to achieve the company's objectives. They are also committed for their work. 
Method of calculation:

$\checkmark \quad$ Weights: (in a 5 scale point likert, the weights are given from 5 to 1 /from strongly agree to Strongly Disagree).

$\checkmark \quad$ Weighted frequency: Calculated by multiplying the each response by the weights.

$\checkmark \quad$ Weighted mean: weighted frequency divided by total respondents.

$\checkmark \quad$ Table mean: the sum of each weights divided by five.

Table 9: The Company's advertising strategy

\begin{tabular}{|l|c|c|}
\hline \multirow{2}{*}{ Best strategy of advertising } & \multicolumn{2}{|c|}{ Respondents in } \\
\cline { 2 - 3 } & Number & Percentage \\
\hline Media (TV, Radio, Newspaper) & 15 & $42.9 \%$ \\
\hline Word of mouth & 8 & $22.9 \%$ \\
\hline Free sampling & 4 & $11.4 \%$ \\
\hline Internet & 2 & $5.7 \%$ \\
\hline Billboard & 6 & $17.1 \%$ \\
\hline Total & 35 & $100 \%$ \\
\hline
\end{tabular}

Source: Own Survey, 2014

The table 9 clearly reveals that the best strategy of advertising is through media communication (TV, Radio, newspaper) as $15(42.9 \%)$ of the respondents replied and $8(22.9 \%)$ responses filled that the finest advertising strategy is word of mouth. $10(28.5 \%)$ of the respondents said the best advertising strategy of the company is through free sampling and billboard. The remaining 5.7\% responded as the preeminent way of advertising means is through internet websites.

From this we can concluded that the best way of advertising means of the company's Products are through media advertisement. This media advertisement includes TV-shows the facial expression, Radio-reaches at least in all regions, and newspapers. Generally advertising can reach geographically dispersed buyers efficiently.

Table 10: Appropriateness of the Company promotional tools

\begin{tabular}{|l|c|c|c|c|c|c|}
\hline \multirow{2}{*}{$\begin{array}{l}\text { Effectiveness } \\
\text { promotional tools }\end{array}$} & of & \multicolumn{2}{|c|}{ Least effective (1) } & \multicolumn{2}{c|}{ Effective (2) } & \multicolumn{2}{c|}{ Most effective (3) } \\
\cline { 2 - 7 } & Number & Percentage & Number & Percentage & Number & Percentage \\
\hline Advertising & - & - & 13 & $37.1 \%$ & 22 & $62.9 \%$ \\
\hline Personal selling & 1 & $2.9 \%$ & 31 & $88.6 \%$ & 3 & $8.5 \%$ \\
\hline Sales promotion & - & - & 15 & $42.9 \%$ & 20 & $57.1 \%$ \\
\hline Public relation & 2 & $5.7 \%$ & 14 & $40 \%$ & 19 & $54.3 \%$ \\
\hline
\end{tabular}

Source: Own Survey, 2014

Table 10 reveals, as a majority of the respondents replied advertising; sales promotion and public relations are the most effective mechanisms of the company's promotional tools and the other majority of respondents indicate that personal selling is effective.

These all indicate the company's promotional mix strategies are vital for the marketing of products. It creates a good image for the MOHA and gained popularity as the company's perspectives of quality products. Moreover, the managers underlined about the promotional tools as the company gives attention for it and go beyond using Medias or vehicles; it also gives emphasis for social marketing activities like:

* Helping the unemployed by creating jobs (especially by building kiosks, manually operated delivery carts)

* Helping senior citizens through Marry Joy(well-known local NGO)

* Participate in community development, sponsorship(supporting outstanding students, graduation magazines)

* Running Pepsi week in different high schools to help them in upgrading their knowledge through question and answer programs

* Participating in HIV/AIDS prevention

* Contributing to popular events by means of sponsoring various exhibitions, music festivals, public gatherings, research forums etc.

\section{Interview Analysis}

To gather more information about marketing mix strategies of Hawassa Millennium Pepsi-cola plant, interview questions were forwarded to the marketing managers of the company. Accordingly the interviewee's responses to the questions are depicted briefly as follows. However, most interview responses are presented and analyzed in the questionnaire analysis part as a supportive response.

Regarding the competitors and the marketing mix strategy designed to win the competitors

Currently, there are some of the competitors in the market, such as; Coca-Cola, Ambo mineral water and 
Abyssinia mineral water, among of them Coca-cola is the major competitor.

This implies that there is a close competition in the market. The Hawassa Millennium Pepsi-cola plant is doing better than its competitors. For example, beyond delivering quality products and selecting best partners, The Company's marketing mix strategy focuses on implementing an efficient distribution network along with creative and innovative marketing. It gives special attention in training and upgrading the skills and competence of employees and partners. Furthermore the Plant has contributed a lot in social activities such as HIV/AIDS, sponsor different sport teams with a view to developing healthier citizens, urban sanitation, participate in the development of arts, helping senior citizens through Marry Joy (well-known local NGO), helping to eradicate bilharzias and running Pepsi week in different high schools to help them in upgrading their knowledge through question and answer programs.

\section{Problems of marketing mix strategy implementation}

In fact when you run a business, everything might not be easily accomplished. Likewise the company faced with some problems while implementing the marketing mix strategies. The interviewee forwarded the following problems regarding the marketing mix strategy implementation.

These are:

$\checkmark$ Economic problem: - as we know the income of individuals are not equal, some may have good income, in the contrarily some may not have enough money even to eat bread. Due to these financial problems, all people may not be drinking our products.

$\checkmark$ Close competition: - there are direct (substitute) local competitors in the market. These competitors may affect our marketing mix strategy.

$\checkmark$ Seasonality: - there is some seasonality of consumption of MOHA products. When the declining of coffee and cash crops prices which is unsatisfactory for distributors and customers. So, during this time there will be less consumption.

$\checkmark$ Shortage of supplies, there is a high demand in the market

$\checkmark$ High cost of advertising program

$\checkmark$ Efficiency and effectiveness of agents

These all implies that the company has faced a problem of implementing the marketing mix strategies and these problems may hinder the strategies to not to achieve the objectives of the company successfully.

\section{The marketing mix strategy of the company to achieve its objectives}

As per the interviewee replied, the marketing mix strategy is a complex practice that involves the quality and standard products, the establishment of various and efficient distribution networks, popularizing the product with fair prices and delivering continuous services after distribution. In this connection, the company has done a lot with regard to marketing mix strategies of its products. The marketing mix strategy of the company is effectively practiced and it is customer oriented. This indicates the MOHA's marketing mix strategy is effectively implemented by its employees to achieve its objectives because the workers showed great commitment and dedication to keep the plant and its product popular. These strategies will effectively accomplished by improving the type, quality and quantity of the products, by discarding all out dated machines and substituted them with modern and state of the art technologies, and by using the same bottles used by all products and these do not get broke, bored or eroded easily: the bottles are also distributing in strong and handy creates.

The company also implementing the marketing mix strategies effectively by advertising the product by erecting artistic notice board in towns, at main public squares, sight-catching places, major outlets and inlets, public service stations and on vehicles, by using modern distribution networks to sufficiently supply and distribute to all parts of the country at an affordable prices, by contributing to popular events by means of sponsoring various exhibitions, music festivals, public gatherings, research forums, mass media programs etc and by providing training in the country and abroad to marketing personnel's /staffs and thus improving their capability and capacity.

The managers also explained that there are marketing mix strategy check lists which facilitate the marketing mix strategies to be implemented in effectively. These are: by define what the company is, identify the products that the company provides, identifies the target buyers/end users, and describes the unique characteristics of the products that distinguish them from the competition, define whether the pricing will be above, below, or at parity with the competitors and establish whether the company will lead, follow, or ignore changes in competitors' pricing, identify the distribution channels through which the products will be made available to the target market/end users, describe how advertising and promotions will convey the unique characteristics of the products, describe any research and development activities or market research plans that are unique to the business, describe the image or personality of the company and its products. These shows the employees can accomplish their duties easily by referring the marketing mix strategy check lists as a result the marketing mix strategy of the company will be implemented successfully. 


\section{Product strategy of the company}

Company should be eager enough to keep their customers satisfied through their product strategy because the most important asset for the organization is the buyers themselves. Good product strategy can build good brand image which keeps loyal customers happy.

In an interview made with the marketing manager, Ato Bizuneh, in addition to those products currently offered by the company, it has been found that detailed marketing research has been conducted to expand the size of the product lines by adding some additional products.

\section{Pricing strategy of the company}

The basic principle in pricing is that the relationship between the price of a product and the value it gives to customers has to be fair and proper. Also, the pricing decision of a factory must be coordinated with product design, distribution and promotion decisions to form a consistent and effective marketing program.

According to the interview made with the marketing department head, the objective of the pricing strategy of the company is to sale the products with a price that could be affordable to the customers and to keep a healthily profit margin (after setting affordable price to the customers the factory achieves a profit in the long run).

\section{CONCLUSION}

The following conclusions were made based on the result of findings.

The employees and managers of the marketing department are genuinely performing their duties to achieve the company's objectives. Hawassa millennium Pepsi-cola plant exploits the 4P's of marketing mix elements to achieve its objectives. These are vital to implement the marketing mix strategy effectively inseparable because each mix affects the other. Therefore, all the mixes are essential for the company to achieve its objectives.

$>\quad$ The Hawassa millennium Pepsi-cola plant provides 5 (five) types of products such as; Pepsi Cola, Mirinda Orange, 7-Up, Mirinda Tonic, and Mirinda Apple are produced by the plant. These products are produced with excellent qualities because in almost all stages of production, the company gives a high emphasis for quality by objecting the lion share of the market. In each stage of the fermentations, there are laboratory technicians who controlled the quality of the products. To sum up, quality product is the key to the company's success.

$>\quad$ In terms of the pricing strategy, the company sets the fair pricing strategy for its customers. The objective is to maximize its profits. It has not any written pricing policy as a result the prices of the products are depends on different factors like; transportation charges, Competitors' costs, Economic factors, Gross profit costs, Overhead costs, Net profit, direct costs. Generally, the pricing strategy is not in a single way because there is a highly turbulent environment and the price also will change according to the conditions. The company like any other organization, prices its products to maximize its profits or the price must cover the whole costs and should gain some profits. But the company works hard to lower its production, overhead and administrative costs by cutting unnecessary operations, increase efficiency and productivity.

$>\quad$ Promotion strategy is also an essential tool for the marketing mix strategy of the company. The company promotional tools are advertising, personal selling, sales promotion and public relation. The Hawassa millennium Pepsi-cola plant promotes its products by means of erecting artistic notice board in towns, at main public squares, sight-catching places, major outlets and inlets, public service stations and on vehicles etc and contributing to popular events by means of sponsoring various exhibitions etc. The company's promotional mix strategies create a good image for the MOHA and gained popularity as the company's perspectives of quality products. Moreover, the company gives emphasis for social marketing activities like; helping the unemployed by creating jobs (especially by building kiosks, manually operated delivery carts), helping senior citizens through Marry Joy(well-known local NGO), helping to eradicate bilharzias, sponsor different sport teams with a view to developing healthier citizens, running Pepsi week in different high schools to help them in upgrading their knowledge through question and answer programs, help the citizens affected by natural disasters and coordinating its employees to help HIV/AIDS victims and participating in prevention as major promotional tools. The best way of advertising means of the company is media advertisement. This media advertisement includes TV, Radio and newspapers.

$>\quad$ Distribution strategies are concerned with the channels of a firm that employ to make its goods available to customers. The distribution system of the company is brilliant and determines the product's marketing presence and the buyers' accessibility to the product. Thus, products availability is so nice and buyers can get the product almost everywhere. The selling processes of the products are mainly through intermediaries. The industry has its own criteria to select the best agent such as; they must have financial capacity, skilled and experienced manpower, necessary logistics (or transportation), they must 
be legal or licensed, has storage capacity, well structured, and reputed. They should also be capable of maintaining closer contact with the company and different roots under its chain.

Even though the marketing mix strategy of the company is effective, there are some problems that the company faced. These are: Transportation problem, shortage of trucks, Economic problem, close competition in the market, remoteness of the area (the imbalances of demand to supply requirements), Seasonality of consumption and efficiency and effectiveness of agents.

\section{Implication for the study}

In order to alleviate the problems in the distribution of the products (to fill the gap between the imbalances of demand and supply requirements), the factory must choose distributors that reach its customers most effectively and other intermediaries that add value to the distributive process. The factory has to do more to expand its local market coverage and increase its market share by selling the products even in rural areas. The Factory should efficiently and effectively use these marketing mix elements for they strongly determine the long run survival in the soft drink industries. Future researchers can also conduct the study on the same problem are by incorporating the other relevant variables to fill the research gap.

\section{REFERENCES}

Aigbiremolen, (2004). "Marketing Banking Services in Nigeria, Lagos: CIBN Press

Aaker, D.A. and Keller, K.L. (1990). "Consumer Evaluations of Brand Extensions." Journal of marketing Research, Vol. 31, pp 243-62.

Anderson and Vince, (2000). Principles of marketing, 1st Ed, Oxford University press NewYork.

Andrew E. (2001). “Marketing: Romantic or Realistic?” Marketing research, summer, pp. 40-42.

Chalachew Adege. (2010). marketing strategy practices, Addis Ababa University Ed. New Jersey, NJ

Harker M, (2009). Marketing: An introductory, Business and Economics. Prentice Hall.

Hart, S.et.al, (2004). Navigates the new product development process, industrial management, London

Inyanga, J. (1998). Marketing for a Developing World, Owerri, Nigeria: Global Press Limited.

Kotler P and Armstrong G, (2010). Principles of marketing; Pearson Prentice Hall, $13^{\text {th ed. }}$

Kurtz and Boone. (2007). Principles of marketing. Central Learning India Pvt. Ltd.

Littler and Wilson. (1995). Marketing strategy, $1^{\text {st }}$ edition, Oxford, London, Boston.

McCarthy, E. J. (1960). Basic Marketing, Managerial Approach Richard D. Irwin.

McDonald, (2004). Marketing plan: How to prepare them, how to use them. $6^{\text {th }}$ Ed, Oxford printing press.

Morden, E. (1991). Elements of Marketing, London: AP Publications. On March 15, 2011.

Paul Fifield. (1994). Marketing strategy, Linacre House, Jordan Hill, Oxford,

Philip K. \& Garry A. (2007). Principles of marketing. $11^{\text {th }}$ edition, prentice Hall, Europe, Mifflin Publishing.

Pride and Ferrel (1987). Marketing: Basic Concepts and Decisions. $5^{\text {th }}$ ed., USA: Houghton Mittlin Company.

Ranchhod, A., and Gurau, C. (2007). Marketing Strategies: A Contemporary Approach. $2^{\text {nd }}$ Edition, Prentice Hall.

Rayport, J. and Sviokla, J. (1994). "Managing in the Market space." Harvard Business Review, NovemberDecember, pp. 141-50.

Tellis, G. (1986). "Beyond the Many Faces of Price: An Integration of Pricing Strategies.” Journal of Marketing, Vol. 50, October, pp. 146-160.

Walker, Boyd and Larreche, (1992). Marketing strategy: planning and implementation, USA. 